\title{
Peran Pendidikan Kewirausahaan dan Dukungan Orangtua pada Siswa SMA
}

\author{
Muhammad Setiawan Kusmulyono \\ Sekolah Bisnis dan Ekonomi, Universitas Prasetiya Mulya \\ Jl. R.A. Kartini (TB. Simatupang), Cilandak Barat, Jakarta 12430
}

\begin{tabular}{l|l}
\hline ARTICLE INFO & ABSTRACT \\
\hline $\begin{array}{l}\text { Keywords: } \\
\text { intention, } \\
\text { high school students, } \\
\text { entrepreneurship, } \\
\text { parents support, } \\
\text { education }\end{array}$ & $\begin{array}{l}\text { Entrepreneurs are cultivated by various factors during their lifetime } \\
\text { to determine their decision to be entrepreneurs. It was believed to lead }\end{array}$ \\
& $\begin{array}{l}\text { the intention of person to choose their career as an entrepreneur. In } \\
\text { Indonesia, the government have challenges to raise the number of } \\
\text { Kata Kunci: } \\
\text { Niat berwirausaha, } \\
\text { siswa SMA, } \\
\text { kewirausahaan, } \\
\text { dukungan orangtua, } \\
\text { dan pendidikan }\end{array}$ \\
strategy is to introduce entrepreneurship education since high school \\
level. High school has an obligation to teach entrepreneurship to \\
students, but the school has authorization to manage the content, \\
methods, and delivery process. But, in the real condition, students in \\
high school level are still being influenced by their parents decision. \\
So, the challenges will not be easier for school to increase the student's \\
intention to be entrepreneurs. By using quantitative approach, this \\
research combined the entrepreneurship education and parents \\
support factors to identify the impact in students decision making to \\
become startup entrepreneur. The results viewed that school roles \\
is more influential than parents support in determining the students \\
decision. It can be occured because in high school students life, school \\
exposure is more systemmatic than parents involvement.
\end{tabular}

\section{SARI PATI}

Seorang wirausaha sangat dipengaruhi oleh berbagai faktor ketika mengambil keputusan untuk terjun ke dunia kewirausahaan. Faktorfaktor tersebut diyakini sebagai salah satu motivasi utama seseorang untuk memilih karir menjadi seorang wirausaha. Indonesia memiliki tantangan yang sangat besar untuk meningkatkan jumlah wirausaha yang dapat mendorong peningkatan standar hidup. Salah satu strateginya, pemerintah Indonesia mulai memperkenalkan kewirausahaan sejak di level Sekolah Menengah Atas. Sekolah Menengah Atas pun menerapkan kebijakan tersebut, namun dengan penyesuaian mulai dari konten, metode pengajaran hingga cara penyampaiannya. Namun, dalam dunia nyata, siswa SMA cenderung sangat dipengaruhi oleh orang tuanya dalam mengambil keputusan. Jadi, hal tersebut tidak akan mudah bagi sekolah untuk meyakinkan niat siswa untuk menjadi seorang wirausaha. Melalui pendekatan kuantitatif, pendelitian ini mencoba mengidentifikasi kombinasi antara pendidikan kewirausahaan di sekolah dengan 
peran orang tua dalam membentuk minat berwirausaha dari siswa SMA. Hasilnya menunjukkan bahwa ternyata pembelajaran di sekolah lebih memiliki pengaruh dibandingkan peran orang tua. Hal ini dapat terjadi karena eksposur sekolah berjalan lebih sistematis dibandingkan upaya orang tua dalam memberikan pengaruhnya di rumah.

(C) 2017 AJEFB, All rights reserved.

\section{PENDAHULUAN}

Sejak tahun 2009, Pemerintah Republik Indonesia telah meluncurkan Program Gerakan Kewirausahaan Nasional (GKN). Gerakan Kewirausahaan Nasional ini dilaksanakan secara serentak oleh seluruh kementerian dengan Kementerian Koordinator Perekonomian sebagai motor penggeraknya. Kementerian Pendidikan Nasional menjadi salah satu yang memberikan respon terhadap Gerakan Kewirausahaan Nasional. Pada tahun 2013, Kementerian Pendidikan Nasional mengujicobakan kurikulum 2013 di tingkat sekolah dasar, sekolah menengah pertama, dan sekolah menengah atas dengan menyertakan kewirausahaan dalam paket mata pelajaran prakarya dan kewirausahaan di level sekolah menengah atas. Harapannya, proses pendidikan kewirausahaan yang berjenjang dapat bermuara pada munculnya wirausaha-wirausaha baru yang tangguh.

Situasi ini menunjukan bahwa arah pendidikan nasional, terutama di level menengah atas mulai berkomitmen untuk mengembangkan pendidikan kewirausahaan. Namun, komitmen ini tidak dapat dikembangkan dengan mudah, dikarenakan area pengembangan pendidikan kewirausahaan masih sangat terbatas. Berdasarkan hasil observasi lapangan, komitmen pemerintah ini perlu disinergikan dengan komitmen sekolah untuk menjalankan pendidikan kewirausahaan. Hal ini dikarenakan terjadinya perbedaan kualitas pendidikan kewirausahaan antar sekolah di Indonesia tergantung dari komitmen sekolahnya.

Perbedaan yang terlihat antara lain upaya sekolah dalam meletakkan mata pelajaran kewirausahaan di dalam kurikulum. Walaupun sudah diamanatkan dalam kurikulum nasional, sekolah masih memiliki keleluasaan untuk memprioritaskan kewirausahaan atau tidak. Pada akhirnya, komitmen ini terlihat pada upaya sekolah dalam mempersiapkan fasilitas pendukung, kesiapan tenaga pengajar, dan peletakan materi kewirausahaan dalam kurikulum.

Berdasarkan wawancara dengan beberapa tenaga pengajar di beberapa sekolah menengah atas, ditemukan beberapa informasi yang bermanfaat. Beberapa sekolah memiliki pilihan dalam meletakkan materi kewirausahaan di dalam kurikulum. Pertama, kewirausahaan disisipkan sebagai bagian dari materi pelajaran ekonomi dan diajarkan oleh guru ekonomi. Kedua, kewirausahaan dilaksanakan sebagai mata pelajaran tersendiri dan diajarkan oleh guru yang ditunjuk sekolah. Guru ini bisa saja berasal dari guru ekonomi, namun tidak jarang ditemukan guru-guru dengan latar belakang biologi, fisika, kimia, bahkan agama, diminta untuk menjadi pengajarnya. Ketiga, kewirausahaan dijadikan sebagai bagian dari ekstrakurikuler dengan membentuk komunitas atau organisasi informal seperti 
klub wirausaha. Keempat, sekolah tidak menyediakan bagian khusus tentang wirausaha, namun menyediakan wadah rutin seperti pameran usaha bagi siswanya yang ingin memamerkan hasil kreativitasnya untuk diperjualbelikan.

Pada sisi sekolah, keragaman komitmen ini menjadikan perwujudan pendidikan kewirausahaan di level sekolah menengah atas menjadi menantang. Tantangannya adalah apakah komitmen tersebut mampu mendorong siswa untuk memiliki minat berwirausaha yang lebih tinggi selepas menamatkan pendidikannya.

Pada sisi lain, minat berwirausaha pada siswa sekolah tidak hanya didominasi oleh peran sekolah, namun juga terdapat peran orangtua. Peran orangtua sangat relevan karena keputusan mengenai sekolah yang akan diambil oleh siswa pada level pendidikan menengah atas, masih merupakan domain dari orangtua. Latar belakang orangtua yang beragam, baik pengusaha maupun profesional, juga turut berkontribusi terhadap upaya orangtua untuk mendorong minat dan cita-cita anaknya selepas menamatkan pendidikannya.

Oleh karena itu, penelitian ini dilaksanakan untuk mengetahui peran sekolah dan orangtua dalam mendorong minat berwirausaha dari siswa di level pendidikan menengah atas di Indonesia. Penelitian ini penting untuk dilakukan agar dapat diketahui faktor apa yang paling berpengaruh kepada minat siswa untuk memiliki usaha di masa depan.

Penelitian ini mengambil konteks pada sekolah yang memiliki komitmen untuk menyelenggarakan mata pelajaran kewirausahaan secara khusus dan juga menyediakan pameran bisnis sebagai salah satu ajang untuk implementasi karya kreatif dari siswa yang belajar mata pelajaran kewirausahaan. Sekolah ini menyelenggarakan mata pelajaran kewirausahaan bagi siswa kelas X, XI, dan XII, namun fokus lebih tinggi dilaksanakan pada saat siswa studi di kelas XII.

\section{Kerangka Teoritis dan Hipotesis Peran Pendidikan Kewirausahaan}

Pendidikan kewirausahaan termasuk arus baru dalam keilmuan di manajemen. Namun, beberapa penelitian telah memberikan indikasi kontribusi pendidikan kewirausahaan terhadap penciptaan bisnisbisnis baru. Penelitian yang dilakukan oleh Lestari dan Wijaya (2012) di sebuah perguruan tinggi menunjukkan bahwa pilihan karir berwirausaha dapat terwujud dengan adanya pendidikan kewirausahaan yang membantu siswa dalam memiliki pola pikir, sikap, dan perilaku wirausaha. Sebuah penelitian dalam konteks studi longitudinal yang dilakukan oleh Varela dan Jimenez (2001) juga menunjukkan bahwa level kewirausahaan tertinggi diperoleh oleh universitas yang menginvestasikan pendidikan kewirausahaan bagi mahasiswanya dibandingkan universitas yang tidak melakukannya.

Disertasi yang dilakukan oleh Lorz (2011) menunjukkan bahwa penelitian tentang pendidikan kewirausahaan sejak tahun 1984 hingga 2010 telah menghasilkan artikel tentang pendidikan kewirausahaan sebanyak 41 buah. Dari jumlah tersebut, 33 artikel menunjukkan bahwa pendidikan kewirausahaan memberikan dampak positif terhadap minat berwirausaha, 2 artikel menunjukkan dampak negatif terhadap minat berwirausaha, dan 6 artikel sisanya menunjukkan hasil campuran, yaitu tidak signifikan memberikan dampak positif maupun negatif terhadap minat berwirausaha.

Salah satu penelitian yang membahas tentang 
dampak positif pendidikan kewirausahaan terhadap minat berwirausaha adalah Bakotic dan Kruzic (2010). Penelitiannya menunjukkan bahwa pendidikan menjadi salah satu faktor dalam variabel dukungan lingkungan yang mempengaruhi sikap dan minat kewirausahaan. Penelitian $\mathrm{Wu}$ dan $\mathrm{Wu}$ (2008) menunjukkan bahwa dampak potensial yang dapat ditimbulkan dari pemberian pendidikan kewirausahaan pada level pendidikan tinggi adalah adanya perubahan dalam pengembangan aspek personal seperti nilai dan sikap, perubahan dalam kemampuan, dan perubahan yang dapat memberikan dampak sosial.

Pendidikan kewirausahaan sendiri memiliki perdebatan dalam definisinya. Menurut Fayolle dkk (2006), pendidikan kewirausahaan merupakan proses pendidikan untuk mempersiapkan keterampilan dan sikap berwirausaha dengan upaya mengembangkan kualitas-kualitas personal yang unggul. Fayolle dkk (2006) juga menambahkan bahwa pendidikan kewirausahaan, terutama pada level pendidikan dasar dan menengah tidak harus berfokus pada penciptaan bisnis-bisnis baru.

Pendidikan kewirausahaan menurut Isaacs dkk (2007) adalah suatu struktur formal yang dipergunakan untuk menyampaikan pengetahuan tentang kompetensi berwirausaha yang diterjemahkan dalam konsep, keterampilan, dan kesadaran mental yang dilakukan oleh individu dalam memulai dan menjalankan usahanya. Konteks yang diterangkan dalam penelitian Isaacs dkk (2007) cukup bertentangan dengan konsep yang dijelaskan oleh Fayolle dkk (2006) dalam penelitiannya.

Fayolle dkk (2006) lebih mengarahkan pendidikan kewirausahaan pada upaya peningkatan kualitas individu yang unggul dan memenuhi kualifikasi untuk menjadi pengusaha tanpa harus bermuara menjadi seorang pengusaha. Namun, dalam konteks Isaacs dkk (2007), pendidikan kewirausahaan lebih dikaitkan pada peran sebuah usaha dalam melakukan utilisasi sumber daya untuk memberikan manfaat sebesar-besarnya bagi komunitas.

Pada penelitian lain yang dilakukan oleh Linan (2004) menunjukan bahwa terdapat 4 pendekatan berbeda dalam menjalankan program pendidikan kewirausahaan. Pendekatan pertama adalah pendidikan untuk meningkatkan kesadaran berwirausaha. Pendekatan kedua adalah pendidikan untuk usaha pemula. Ketiga adalah pendidikan untuk dinamika berwirausaha, dan keempat adalah pembelajaran berkelanjutan bagi wirausaha.

Penelitian Linan (2004) ini tentunya dapat menjembatani konsep dan konteks yang berbeda dalam penelitian antara Fayolle (2006) dan Isaacs (2007). Penelitian Linan (2004) menunjukan bahwa pendidikan kewirausahaan dapat diterapkan secara berbeda tergantung dengan sasaran yang ingin dipengaruhi. Menurut Cho (1998) salah satu hal yang terpenting dalam proses pendidikan kewirausahaan adalah mampu mendukung motivasi, pengetahuan, dan keterampilan siswa dalam mempersiapkan sebuah usaha baru. Penelitian Linan (2004) ini juga diperkuat oleh temuan yang dirilis oleh OECD (2005) yang menunjukkan belum terdapatnya model tunggal yang dapat dijadikan panduan utama dalam pendidikan dan pelatihan kewirausahaan dan bagaimana kewirausahaan tersebut sebaiknya diajarkan.

\section{Peran Dukungan Orangtua}

Menurut Prabhu dan Thomas (2014), secara tradisional, kewirausahaan yang berkembang di masyarakat difasilitasi oleh 
adanya ekosistem berwirausaha dan jejaring bisnis yang memiliki hubungan saling ketergantungan. Konsep ini menunjukkan kesesuaian dengan teori yang dikemukakan oleh Ajzen (1991) yang menunjukkan intensi sangat mempengaruhi pola perilaku yang akan dilakukan oleh seseorang.

Penelitian yang dilakukan oleh Malebana, dkk (2015) menunjukkan bahwa orangorang yang berada di sekitar dapat memberi dukungan dan keyakinan untuk melaksanakan kegiatan kewirausahaan. Fatoki (2014) dalam penelitiannya tentang pendidikan kewirausahaan di Afrika Selatan menunjukkan bahwa keterlibatan orangtua yang cukup tinggi dapat mempengaruhi keterampilan berwirausaha dari anak-anak.

Penelitian dari Marhaini dkk (2014) menyampaikan bahwa agar anak dapat memiliki karir sebagai seorang wirausaha, maka orangtua harus membuka kesempatan untuk berkomunikasi dengan anak-anak terkait masa depan mereka terutama dalam bidang kewirausahaan. Marhaini dkk (2014) juga menambahkan bahwa dukungan positif dan konsisten dapat meningkatkan kemungkinan anak untuk memilih karir dalam bidang wirausaha di masa depan.

Dukungan keluarga ini dirasakan cukup signifikan karena keluarga dianggap memiliki peran sebagai bagian dari kelompok berwirausaha (Ruef, 2010). Nordqvist dan Melin (2010) juga mengindikasikan bahwa potensi terbesar bagai seseorang untuk mulai berwirausaha dapat ditemukan di dalam keluarga. Dalam penelitian Pant (2015) terdapat 3 hal yang menjadikan keluarga sebagai salah satu unsur penting dalam munculnya semangat berwirausaha, yaitu keluarga dianggap sebagai kelompok pendukung, keluarga menyediakan sumber daya, dan keluarga mendukung seperti layaknya menjalankan bisnis keluarga.

\section{METODE PENELITIAN}

\section{Pengumpulan Data}

Analisis dalam kajian literatur menunjukkan peran sekolah dalam mengembangkan pendidikan kewirausahaan dapat dikaji dari tiga aspek, yaitu kurikulum, tenaga pengajar, dan fasilitas yang tersedia. Ketiga aspek tersebut dirangkum menjadi aspek peran sekolah. Konsep kurikulum dan tenaga pengajar merupakan hal umum yang terdapat dalam suatu sistem pendidikan sekolah. Namun, dalam penelitian Haruman, Hendri, dan Hermawan (2009), menunjukkan adanya pengaruh positif pengajar dan kurikulum dalam kualitas lulusan. Oleh karena itu, merujuk pada penelitian tersebut, disusunlah instrumen yang kemudian disesuaikan dengan kondisi sekolah menengah atas. Pada aspek fasilitas, disesuaikan juga merujuk peneilitian Haruman, Hendri, dan Hermawan (2009) yang lebih berfokus pada aspek fasilitas di perguruan tinggi. Oleh karena itu, dilakukan sedikit pengembangan konten instrumen untuk disesuaikan dengan kebutuhan di sekolah menengah atas.

Pada kajian keluarga, aspek yang digunakan lebih beragam dengan tujuan untuk mengidentifikasi peran keluarga dalam mendorong minta berwirausaha anaknya di level pendidikan sekolah menengah atas. Instrumen dikembangkan sesuai dengan tinjauan literatur yang sudah dilakukan.

H1: Pihak sekolah dan orangtua memiliki pengaruh terhadap minat siswa SMA untuk berwirausaha

Variabel peran sekolah merupakan variabel bebas pertama (XI) yang didefinisikan sebagai aspek-aspek dalam konteks sekolah yang mendukung berjalannya pendidikan kewirausahaan. Pada variabel bebas pertama, 


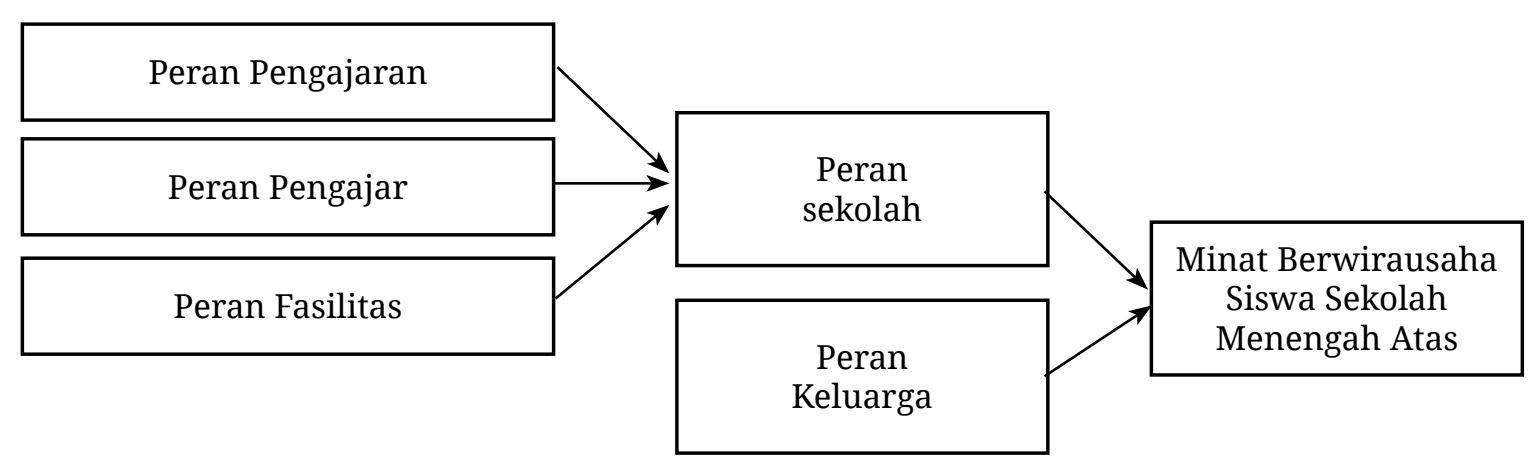

Gambar 1. Kerangka Berpikir Penelitian

peneliti mengklasifikasikan adanya peran dari pengajaran, pengajar, dan fasilitas.

Variabel peran keluarga (X2) merupakan variabel bebas kedua yang didefinisikan sebagai aspek-aspek dalam keluarga yang mendukung siswa untuk memiliki minat berwirausaha. Variabel terikat pertama (Y1) adalah variabel terkait minat berwirausaha anak SMA yang menunjukkan gambaran mengenai aspek minat untuk berwirausaha bagi anak SMA.

Subyek dalam penelitian ini adalah siswa kelas XII sekolah menengah atas yang di dalam sekolahnya telah mengajarkan kewirausahaan sebagai mata pelajaran sekaligus menempatkan kewirausahaan sebagai salah satu keunggulan sekolahnya dengan rutin menyelenggarakan pameran bisnis sebagai ajang untuk menunjukkan hasil kinerja dari siswanya. Sekolah Menengah Atas ini demi kepentingan penelitian disamarkan namanya dengan nama SMA XYZ.

Limitasi yang terdapat dalam penelitian ini adalah tidak dibedakannya antara siswa yang mengambil jurusan IPA dengan IPS dikarenakan dalam kurikulum yang diajarkan oleh sekolah ini, kedua jurusan tersebut memperoleh bobot pelajaran kewirausahaan yang sama dengan pengajar yang sama.

Data dikumpulkan dalam kurun waktu
Bulan Maret hingga April 2017 dan menggunakan skala Likert dalam kuesioner yang dipergunakan. Skor untuk tiap-tiap item bergerak dari 1 hingga 5 dengan memperhatikan sifat item sangat tidak setuju hingga sangat setuju. Sebelum menuju kesimpulan dan analisis terhadap variabel yang diuji, setiap pertanyaan di dalam variabel kuesioner yang diujikan terlebih dahulu diuji validitas dan reliabilitasnya. Hasil dari uji validitas dan reliabilitas menghasilkan variabel yang relevan untuk diuji dengan menggunakan analisis regresi.

\section{HASIL DAN PEMBAHASAN}

Uji validitas yang dilakukan dalam penelitian di atas menunjukkan beberapa informasi. Pada variabel peran sekolah yang terdiri dari 3 variabel bebas, yaitu peran pengajaran, peran pengajar, dan peran fasilitas, ketiga aspek tersebut menyajikan data yang erat keterkaitannya dan seluruh aspek yang ditanyakan dalam kuesioner dapat dipergunakan. Hal ini menunjukkan alat ukur yang dipergunakan tergolong tepat dalam mengukur apa yang ingin diukur dalam penelitian ini karena seluruh hasil uji validitas menunjukkan angka muatan faktor diatas 0,5 .

Namun, pada uji reliabilitas aspek peran fasilitas, terdapat nilai cronbach alpha yang lebih rendah $(0,427)$ dari nilai cronbach alpha 
Tabel 1. Profil Respondens

\begin{tabular}{lll}
\hline Jumlah Responden & $:$ & 170 siswa \\
\hline Jumlah Responden Pria & $:$ & 79 siswa [46,5\%] \\
\hline Jumlah Responden Wanita & $:$ & 91 siswa [53,5\%] \\
\hline Rata-rata Usia Responden & $:$ & 17 tahun \\
\hline Jumlah Responden dengan Orangtua Memiliki Usaha & $:$ & 94 siswa [55,3\%] \\
\hline Jumlah Responden dengan Orangtua & $:$ & 76 siswa [44,7\%] \\
Tidak Memiliki Usaha & \\
\hline
\end{tabular}

Tabel 2. Hasil Uji Validitas dan Uji Reliabilitas

\begin{tabular}{|c|c|c|c|}
\hline No & Variabel & $\begin{array}{l}\text { Muatan } \\
\text { Faktor }\end{array}$ & $\begin{array}{l}\text { Cronbach } \\
\text { Alpha }\end{array}$ \\
\hline & Peran Sekolah [All] & & 0,728 \\
\hline & Peran Sekolah [Kurikulum] & & 0,613 \\
\hline SE 1 & $\begin{array}{l}\text { Saya memperoleh pengetahuan berwirausaha dari } \\
\text { pengajaran di sekolah }\end{array}$ & 0,804 & \\
\hline SE 2 & $\begin{array}{l}\text { Saya senang mengikuti seminar wirausaha, baik dari sekolah } \\
\text { maupun di luar sekolah }\end{array}$ & 0,610 & \\
\hline \multirow[t]{2}{*}{ SE 3} & $\begin{array}{l}\text { Saya memahami dengan baik tentang mata pelajaran } \\
\text { kewirausahaan di sekolah }\end{array}$ & 0,828 & \\
\hline & Peran Sekolah [Pengajar] & & 0,756 \\
\hline SE 4 & $\begin{array}{l}\text { Guru sekolah memiliki pengetahuan yang baik tentang } \\
\text { kewirausahaan }\end{array}$ & 0,791 & \\
\hline SE 5 & $\begin{array}{l}\text { Guru saya memberikan motivasi dalam peningkatan minat } \\
\text { berwirausaha saya }\end{array}$ & 0,864 & \\
\hline \multirow[t]{2}{*}{ SE 6} & $\begin{array}{l}\text { Saya memahami dengan baik materi kewirausahaan yang } \\
\text { diajarkan oleh guru }\end{array}$ & 0,807 & \\
\hline & Peran Sekolah [Fasilitas] & & 0,471 \\
\hline SE 7 & $\begin{array}{l}\text { Sekolah saya memiliki fasilitas yang memadai untuk } \\
\text { meningkatkan minat berwirausaha saya }\end{array}$ & 0,694 & \\
\hline SE 8 & $\begin{array}{l}\text { Perpustakaan menyediakan buku-buku bacaan yang cukup } \\
\text { tentang kewirausahaan }\end{array}$ & 0,762 & \\
\hline SE 9 & $\begin{array}{l}\text { Saya senang membaca artikel internet tentang bisnis dan } \\
\text { kewirausahaan }\end{array}$ & 0,650 & \\
\hline No & Variabel & $\begin{array}{l}\text { Muatan } \\
\text { Faktor }\end{array}$ & $\begin{array}{l}\text { Cronbach } \\
\text { Alpha }\end{array}$ \\
\hline & Peran Keluarga & & 0,827 \\
\hline OT 1 & Orang tua saya selalu memberikan perhatian kepada saya & 0,740 & \\
\hline OT 2 & Keluarga saya mengajarkan nilai moral yang baik & 0,875 & \\
\hline OT 3 & $\begin{array}{l}\text { Orang tua mengajarkan saya norma-norma yang baik di } \\
\text { lingkungan keluarga }\end{array}$ & 0,864 & \\
\hline OT 5 & $\begin{array}{l}\text { Orang tua selalu memberikan motivasi agar kelak saya } \\
\text { menjadi orang yang sukses }\end{array}$ & 0,514 & \\
\hline
\end{tabular}


OT 7 Komunikasi merupakan hal yang sangat penting dalam keluarga

OT 8 Komunikasi yang baik mampu menciptakan harmonisasi dalam keluarga

Minat Berwirausaha Siswa SMA

MB 1 Saya ingin menjadi wirausaha muda yang sukses

MB 2 Saya akan memulai berwirausaha setelah lulus sekolah

0,724

MB 3 Saya mau bekerja keras demi menjadi wirausaha muda

0,800 sukses bisnis melalui wirausaha sekitar saya dengan usaha yang saya dirikan

yang dapat diterima, yaitu 0,6. Namun, jika seluruh aspek disatukan dalam variabel peran sekolah, nilai cronbach alpha yang diperoleh sebesar 0,728 dapat diterima. Informasi ini menunjukkan bahwa alat ukur dalam aspek pengajaran dan pengajar termasuk handal untuk dipergunakan, sedangkan alat ukur untuk aspek fasilitas perlu dikembangkan lebih lanjut agar lebih handal dan memiliki hasil yang lebih konsisten.

Pada aspek peran keluarga, peneliti mengajukan 8 variabel sebagai faktor yang dipergunakan untuk mengidentifikasi peran keluarga dalam mendukung minat berwirausaha untuk siswa SMA. Namun, dari 8 variabel yang ditanyakan, terdapat 2 variabel yang tidak valid untuk digunakan sebagai alat ukur, yaitu variabel orang tua mendukung saya untuk menjadi wirausaha dan variabel orang tua mau membantu saya berwirausaha dari segi finansial. Jika ditinjau dari pembahasan kajian literatur, terdapat kontradiksi antara hasil awal dengan kajian yang dibahas. Namun, secara lebih lengkap, pembahasan akan disajikan dibagian implikasi manajerial. Pada sisi uji reliabilitas, nilai cronbach alpha yang dimiliki sebesar 0,827 tergolong baik. Hal ini menunjukkan bahwa alat ukur ini dapat diandalkan untuk mengukur aspek peran keluarga.

Pada aspek minat berwirausaha siswa SMA, peneliti mengajukan 10 variabel sebagai faktor yang dipergunakan untuk mengidentifikasi minat berwirausaha siswa SMA. Namun, terdapat 2 variabel yang memiliki nilai muatan faktor kurang dari yang dipersyaratkan. Kedua variabel tersebut adalah saya yakin terhadap kemampuan saya bahwa saya akan sukses dan saya mampu menangani masalah yang saya hadapi. Oleh karena itu, dalam aspek ini, hanya terdapat 8 variabel yang memiliki nilai muatan faktor yang dipersyaratkan. Pada sisi uji reliabilitas, nilai cronbach alpha yang dimiliki oleh aspek ini sebesar 0,881 termasuk baik dan mampu menunjukkan bahwa alat ukur ini dapat diandalkan untuk mengukur aspek minat berwirausaha. 
Tabel 3. Hasil Analisis Regresi

\begin{tabular}{lcc}
\hline Hubungan Antar Variabel & Beta & t-value \\
\hline Peran Sekolah $\longrightarrow$ Minat Berwirausaha Siswa SMA & 0,302 & 4,131 \\
Peran Keluarga $\longrightarrow$ Minat Berwirausaha Siswa SMA & 0,190 & 2,601 \\
$\mathrm{R}$ & 0,392 & \\
$\mathrm{R}^{2}$ & 0,154 & \\
$\mathrm{~F}$ value & 15,183 & \\
Sig & 0,000 & \\
Adjusted $\mathrm{R}^{2}$ & 0,144 & \\
\hline
\end{tabular}

Hasil analisis regresi linear yang disajikan dalam tabel diatas menunjukkan hubungan antara peran sekolah dan peran keluarga dengan minat berwirausaha siswa SMA. Perhatian pertama diarahkan pada nilai koefisien determinasi ganda (R2) yang menunjukkan angka 0,154. Angka ini mengindikasikan bahwa variabel terikat yang dapat dijelaskan oleh kedua variabel bebas hanya sebesar 15,4\%. Informasi ini menunjukkan bahwa hampir $84,6 \%$ sisanya dijelaskan oleh variabel lain.

Pada sisi nilai signifikansi, nilai 0,000 menunjukkan bahwa variabel peran sekolah dan peran orang keluarga secara bersama-sama mempengaruhi variabel minat berwirausaha siswa SMA dengan tingkat keyakinan 95\%. Hal ini dapat dilihat dengan nilai signifikansi $(0,000)$ yang lebih kecil dari nilai alpha (95\%). Pada nilai $t$ dalam perhitungan analisis regresi diatas menunjukkan bahwa nilai kedua variabel memiliki pengaruh signifikan dalam menjelaskan hubungan karena nilai t hitung (4,131 dan 2,601) lebih besar dari nilai t uji sebesar 1,96 .

Hasil regresi diatas juga menunjukkan bahwa variabel peran sekolah $(0,302)$ lebih berkontribusi dalam mempengaruhi minat berwirausaha siswa SMA dibandingkan dengan variabel peran keluarga $(0,190)$.
Dalam perhitungan analisis regresi terpisah, aspek dari peran sekolah yang lebih berkontribusi terhadap minat berwirausaha siswa SMA adalah peran pengajaran $(0,402)$ dibandingkan dengan peran guru $(-0,311)$, dan peran fasilitas $(0,298)$.

Jika ditinjau dari hipotesis yang diajukan di kerangka awal penelitian, maka hipotesis awal yang diajukan dapat diterima karena variabel peran sekolah dan peran keluarga memiliki pengaruh signifikan terhadap minat berwirausaha siswa SMA.

\section{Temuan}

Hasil analisis regresi linear menunjukkan bahwa kombinasi antara peran sekolah dan peran orang tua dalam meningkatkan minat berwirausaha siswa SMA memberi kontribusi sekitar 15,4\%. Namun, aras peran sekolah memberi kontribusi lebih besar dalam hubungan persamaan dalam menentukan minat berwirausaha siswa SMA, yaitu sekitar 30,4\% dengan kontribusi lebih besar diberikan oleh aspek pengajaran.

Hasil dari analisis regresi ini tentunya sesuai dengan hasil dari penelitian Lestari dan Wijaya (2012) yang menunjukkan bahwa pilihan karir berwirausaha dapat terwujud dengan adanya pendidikan kewirausahaan yang membantu siswa dalam memiliki pola pikir, sikap dan perilaku wirausaha. Di dalam 
konteks penelitian ini, siswa yang dijadikan responden penelitian adalah siswa yang telah duduk di kelas XII. Hal ini menunjukkan bahwa responden telah memiliki eksposur atas pendidikan kewirausahaan yang dilakukan pada SMA tersebut selama hampir 2,5 tahun. Oleh karena itu, hal ini menjadi sangat wajar karena eksposur yang diterima sudah cukup besar.

Salah satu unsur penguat dari SMA yang dijadikan konteks penelitian ini adalah sudah diajarkannya kewirausahaan sebagai salah satu mata pelajaran dalam kerangka kurikulum 2013. Selain itu, SMA XYZ ini merupakan bagian dari sebuah yayasan pendidikan besar yang memiliki SMA yang tersebar hampir di seluruh wilayah Pulau Jawa dan memiliki perhatian yang sangat besar di dalam bidang pendidikan. Yayasan dari SMA XYZ pun telah membuat suatu panduan dalam pengajaran kewirausahaan di sekolah-sekolah yang berafiliasi di bawahnya. Merujuk hasil penelitian Isaacs dkk (2007) adanya kurikulum ini menunjukkan bahwa sekolah telah memiliki struktur formal yang dipergunakan untuk menyampaikan pengetahuan tentang kompetensi berwirausaha.

Pada sisi keluarga, kontribusi yang diberikan dalam minat berwirausaha siswa SMA cenderung lebih minimum jika dibandingkan dengan kontribusi dari sisi sekolah. Walaupun, dari sisi jumlah responden, 55,3\% siswa yang menjadi responden memiliki orang tua dengan latar belakang pengusaha. Beberapa temuan dapat dijadikan sebagai bahan argumentasi dalam menjelaskan hasil yang cukup bertolak-belakang ini, salah satunya adalah penelitian Malebana dkk (2015) yang menunjukkan bahwa orang-orang yang berada di sekitar dapat memberi dukungan dan keyakinan untuk melaksanakan kegiatan kewirausahaan.
Pertama, dapat dijadikan sebagai bahan argumentasi adalah orang tua siswa yang menjadi pengusaha tidak menjadi pengusaha melalui jalur pendidikan formal, atau tidak menempuh pendidikan kewirausahaan dalam proses belajarnya. Sebagian besar jenis usaha yang disampaikan oleh responden dalam diskusi diluar penelitian kuantitatif adalah usaha-usaha yang lebih banyak dilakukan di bidang perdagangan, seperti pemasok bahan baku, atau memiliki toko. Temuan lebih lanjut memang diperoleh bahwa beberapa bidang usaha yang ditekuni oleh orang tua siswa lebih banyak berkaitan dengan pengalaman orang tua siswa maupun bidang kompetensi yang dimiliki sejak sekolah.

Dalam situasi orang tua berwirausaha namun tidak sesuai dengan bidang ilmu atau dapat dikatakan mereka mampu membangun usaha secara otodidak, orang tua cenderung mengabaikan proses pendidikan kewirausahaan sebagai faktor penting dalam menentukan minat berwirausaha siswa. Hal ini terjadi karena orang tua akan melakukan refleksi terhadap pengalaman pendidikan yang dialaminya. Mereka mengangap bahwa proses yang dulu dialami dulu tidak memiliki kontribusi terhadap kesuksesan usaha yang saat ini diperolehnya, sehingga hal ini mendorong mereka untuk berpikir bahwa pendidikan yang dialami anaknya juga tidak akan berkontribusi untuk kesuksesan usahanya. Hal ini tidak sejalan dengan usulan dalam penelitian Marhaini dkk (2011) yang menyampaikan bahwa agar anak dapat memiliki karir sebagai seorang wirausaha, maka orang tua harus membuka komunikasi dengan anak-anak mereka terkait karir di masa depan.

\section{Kontribusi Literatur}

Salah satu kontribusi terhadap kajian literatur dalam penelitian ini adalah rendahnya aspek fasilitas dalam mendukung minat siswa untuk 
berwirausaha. Hal ini dapat dimungkinkan karena SMA XYZ ini merupakan sekolah dengan kualitas standar nasional dan memiliki segmen siswa menengah atas. Tentunya, bagi siswa yang bersekolah di SMA $\mathrm{XYZ}$, fasilitas yang bagus sudah tergolong dalam hygiene factors.

Diluar ketidakhandalan faktor fasilitas dalam mendukung minat berwirausaha siswa, peran orang tua juga tidak terlalu signifikan dalam hal ini. Oleh karena itu, diperlukan adanya suatu kajian penelitian lebih mendalam terkait peran orang tua yang lebih spesifik agar dapat berdampingan dengan peran sekolah untuk mendukung minat berwirausaha bagi siswa di sekolah menengah atas.

\section{IMPLIKASI PRAKTIS}

Namun, merujuk pada wawancara awal yang dilakukan oleh peneliti kepada pengajar kewirausahaan di SMA XYZ, terdapat beberapa tantangan meskipun panduan pengajaran kewirausahaan telah diberikan. Pertama, guru yang ditunjuk untuk menjadi pengajar kewirausahaan bukan merupakan guru khusus mata pelajaran kewirausahaan, melainkan guru bidang studi lain yang diberikan tugas tambahan untuk menjadiguru kewirausahaan. Kedua, tidak ada pelatihan dan monitoring rutin yang dilakukan oleh pihak yayasan selaku pengarah utama bagi guru-guru ini untuk mengembangkan pengajaran kewirausahaan.

Jika dilihat dari temuan kualitatif di atas yang dilakukan sebelum penelitian kuantitatif dilaksanakan, terlihat adanya tantangan yang cukup serius dalam hal pemberi materi pelajaran. Hal ini dikarenakan, sebagian besar guru bidang studi yang diberikan tugas tambahan tentunya sudah memiliki disiplin ilmu dalam bidang studi yang mereka tekuni. Ketika mengajar, maka secara alamiah, disiplin ilmu bidang studi pengajar akan juga diterapkan dalam pendidikan kewirausahaan. Hal ini cenderung menjadi salah satu tantangan karena umumnya pendidikan kewirausahaan diajarkan dengan lebih luwes.

Pada sisi lain, apa yang dilakukan di SMA XYZ tersebut juga memberikan dampak positif bagi perkembangan minat berwirausaha siswa SMA XYZ dengan kontribusi yang cukup signifikan dalam penelitian ini. Pertama, guru bidang studi dengan disiplin ilmu berbeda memberikan wawasan yang lebih beragam kepada siswa. Dalam salah satu contoh kasus yang terjadi di SMA XYZ adalah guru kewirausahaan yang mengajar adalah guru fisika. Guru tersebut walaupun memiliki disiplin berbeda dan membuat keluwesan pendidikan kewirausahaan menjadi menantang, namun dalam beberapa konsep yang diajarkan mampu menjadi asosiasi yang baik bagi siswanya, salah satunya dengan contoh pelajaran membuat rangkaian listrik untuk lampu.

Selain itu, SMA XYZ ini memiliki perhatian yang sangat besar terhadap kewirausahaan sehingga melakukan hal-hal yang melebihi indikator yang ditetapkan oleh yayasan sekolah tersebut. Salah satunya adalah selalu rutin menyelenggarakan seminar dan pelatihan kewirausahaan yang kemudian dilanjutkan dengan kompetisi kewirausahaan yang wajib diikuti oleh seluruh siswa kelas XII. SMA XYZ pun mengalokasikan dana kegiatan kewirausahaan yang tidak sedikit dengan mengalokasikan dana untuk tiap kelompok siswa yang mengikuti kompetisi kewirausahaan internal. Selain itu, SMA XYZ juga meniadakan pelajaran ketika masa seminar, pelatihan dan kompetisi kewirausahaan sehingga siswa dapat lebih fokus mengikuti aktivitasnya. 
Pada aspek keluarga, dalam sebuah wawancara lain yang dilakukan secara acak dengan responden lainnya mengungkapkan bahwa ada orang tua yang secara eksplisit telah meminta sang anak untuk meneruskan usahanya selepas menamatkan pendidikan tingginya. Bahkan orangtuanya telah menyediakan dana agar sang anak mampu menuntut ilmu di luar negeri di bidang bisnis agar lebih siap ketika menjalankan usahanya kelak. Namun, ada pula orang tua yang secara implisit menyampaikan kepada anaknya terkait cita-cita sang anak. Hal ini yang kemudian menurut responden dapat ditafsirkan berbeda, apakah harus melanjutkan usahanya atau boleh memiliki cita-cita dan karir personal.

Situasi tersebut memberikan informasi yang penting dalam menanggapi hasil penelitian kuantitatif terkait kontribusi keluarga yang lebih sedikit dalam mendukung minat berwirausaha siswa SMA. Sayangnya, di dalam penelitian ini belum menyertakan variabel yang menanyakan perihal dukungan eksplisit orang tua terhadap karir wirausaha selepas sekolah bagi para responden.

\section{Batasan dan Penelitian Lanjut}

Salah satu batasan dalam penelitian ini adalah bahwa kontribusi kedua faktor ini tidak terlalu besar dalam menentukan keputusan mereka untuk berwirausaha. Oleh karena itu, dibutuhkan suatu penelitian literatur lagi untuk mengidentifikasi faktor-faktor lain yang memberi pengaruh terhadap keputusan siswa untuk berwirausaha.

Diluar hal tersebut, salah satu limitasinya lagi adalah bahwa penelitian ini dilaksanakan pada sekolah yang memiliki arah pendidikan kewirausahaan yang lebih jelas. Tentunya, hasil yang diperoleh dari konteks penelitian ini perlu dibandingkan dengan sekolah menengah atas lain yang mungkin belum memiliki panduan pendidikan kewirausahaan yang jelas sehingga dapat diperbandingkan. Pada riset kedepannya, penelitian tentang kajian teori mendalam tentang aspekaspek yang berpengaruh terhadap siswa sekolah menengah atas sangat dibutuhkan untuk menggali faktor-faktor penting yang berkontribusi terhadap minat berwirausaha.

\section{KESIMPULAN}

Kesimpulanyangdapatdiperoleh dariaktivitas penelitian ini adalah sekolah memiliki peran yang signifikan dengan pertumbuhan minat berwirausaha siswa SMA, khususnya dalam konteks penelitian di SMA XYZ ini. Hal ini memberi bukti kontribusi nyata dari Gerakan Kewirausahaan Nasional yang didengungkan oleh pemerintah. Jika dapat dikelola lebih baik lagi, maka pendidikan kewirausahaan dapat memiliki kontribusi yang signifikan dalam pertumbuhan jumlah wirausaha di Indonesia.

Secara lebih teknis, sekolah yang aktif dalam mengembangkan pendidikan kewirausahaan dan memiliki komitmen untuk menjalankannya menjadi hal yang paling penting dibandingkan sekolah yang hanya bertujuan untuk menggugurkan kewajiban. SMA XYZ pun berani mengalokasikan dana kegiatan kewirausahaan dan waktu khusus untuk menjalankan aktivitas kewirausahaan di sekolahnya.

Pada sisi lain, peran keluarga dalam hal ini orang tua masih memiliki kontribusi yang kurang signifikan dalam mendukung minat berwirausaha siswa, walaupun dalam konteks penelitian ini, jumlah orang tua yang memilik usaha lebih dari 50\% responden. Hal ini dapat terjadi salah satunya adalah refleksi orang tua pada pendidikannya saat zaman sekolah yang tidak berkontribusi terhadap bidang wirausaha yang ditekuninya saat ini. Untuk kedepannya, masukan yang dapat 
diberikan oleh peneliti untuk meningkatkan kontribusi yang signifikan baik bagi sekolah dan keluarga adalah sebagai berikut:

1) Semakin meningkatkan variasi keberagaman kegiatan kewirausahaan di sekolah untuk memberikan pengalaman yang lebih baik bagi siswa-siswa.

2) Meningkatkan kualitas pengajar dengan bekerjasama dengan perguruan tinggi yang memiliki program pendidikan kewirausahaan agar dapat lebih memperkuat struktur dan konten pengajaran yang diajarkan ke siswa.

3) Meningkatkan kualitas program yang bersifat tindakan nyata atau praktik, sehingga dapat lebih memperkaya wawasan yang dimiliki oleh siswa.

4) Meningkatkan peran aktif orang tua dalam pendidikan kewirausahaan di sekolah dengan menjalin komunikasi yang baik antara pihak sekolah dan orang tua terkait kegiatan kewirausahaan yang dilakukan oleh siswa.
5) Melakukan refleksi yang lebih mendalam dengan menyertakan informasi-informasi terbaru sehingga orang tua tidak menggunakan persepsi tunggal dalam menilai hal yang baik bagi siswanya.

6) Memberikan gambaran secara eksplisit keinginan orang tua kepada anakanya dengan tetap membuka pintu diskusi dan dialog dengan anak agar dapat mendukung kegiatan yang ingin ditekuni oleh anaknya di masa depan.

Menurut peneliti, dalam penelitian selanjutnya dapat dilakukan penelitian yang lebih mengarah kepada peran keluarga dalam mendukung minat berwirausaha dan hubungan pekerjaan orang tua dengan minat berwirausaha yang dimiliki oleh sang anak. Namun, jika penelitian ini ingin direplikasi, ada baiknya ditambahkan pertanyaan tentang apakah orang tua pernah secara eksplisit menyampaikan keinginannya kepada sang anak.

DAFTAR PUSTAKA

Ajzen, I., (1991). “The Theory of Planned Behavior.” Organizational and Human Decision Processes, 50, pp. 179211.

Bakotic,D., \& Kruzic,D., (2010). ”Students’ Perceptions and Intentions Towards Entrepreneurship: The Empirical Findings From Croatia”, The Business Review, Cambridge, Vol. 14, Num. 2, Summer , 2010

Cho, B. 1998. Study of the effective entrepreneurship education method and its process. Business Education Research, 2(1):27-47

Fatoki, Olawale. (2014). Parental and Gender Effects on the Entrepreneurial Intention of University Students in South Africa. Mediterranean Journal of Social Sciences, MCSER Publishing, Rome-Italy. 5(7).

Fayolle, Alain; Gailly, Benoit; and Lassas-Clerc, Narjisse. 2006. Assessing the Impact of Entrepreneurship Education Programmes: A New Methodology. Journal of European Industrial Training. 30 (9) 701-720.

Haruman,T., Hendri,M.,\& Hendrawan, R., (2009). ”The Influence of Curriculum and Lecturers toward Quality of Entrepreneurial Graduates in Bandung”, in proceding of Indonesian International Conference on Innovation, Entrepreneurship and Sustainability, CIEL, SBM, ITB.

Isaacs, E., Visser, K., J Friedrich C. \& Brijlal, P. 2007. Entrepreneurship education and training at the further education and training (FET) level in South Africa. South African Journal of Education , 27, 613 - 629.

Lestari, B.R dan Trisnadi Wijaya. 2012. Pengaruh Pendidikan Kewirausahaan Terhadap Minat Berwirausaha Mahasiswa Di STIE MDP, STMIK MDP, dan STIE MUSI. Forum Bisnis dan Kewirausahaan Jurnal Ilmiah STIEMDP. Vol. 1 No. 02, pp: 112-119. 
Linan, F. 2004. Intention-based Model of Entrepreneurship Education. Piccola Impressa / Small Business. 3. 11 $-35$

Lorz, Michael. 2011. Dissertation: The Impact of Entrepreneurship Education on Entrepreneurial Intention. University of St. Gallen

Malebana, M.J. \& E. Swanepoel. 2015. Graduate Entrepreneurial Intentions In The Rural Provinces Of South Africa. Department Of Management And Entrepreneurship. Volume 19 Number 1, pp: 89-111.

Marhaini; Dalimunthe, Ritha F; and Qamariah, Inneke. 2014. Role of Parents in Childrens' Career Selection as an Entrepreneur. International Journal of Economics, Commerce, and Management. II (12). 1 - 11

Nordqvist, M., \& Melin, L. (2010). Entrepreneurial families and family firms. Entrepreneurship and Regional Development, 22(3-4), 211-239.

Organisation for Economic Co-operation and Development (2005). OECD SME and Entrepreneurship Outlook 2005. OECD

Pant, Sushil Kumar. 2015. Role of the Family in Entrepreneurship Development in Nepali Society. The Journal of Nepalese Business Studies. IX (1). 37 - 47

Prabhu, Ajit and Thomas, Anisha. 2014. Influence of Parental Factors on the Entrepreneurial Attitude of B School Students. International Journal of Research and Development - A Management Review. 3 (1). 35 - 38

Ruef, M. (2010). The entrepreneurial group: Social identities, relations, and collective action. Princeton and Oxford: Princeton University Press.

Syden, Mishi and Gordon K, Shaw. 2014. Entrepreneurial Awareness among High School Learners: Case Study of Buffalo City Metropolitan Municipality. Mediterranean Journal of Social Sciences. 5 (8). 146 - 159

Undang-undang RI Nomor 20 Tahun 2003

Varela, R. \& Jimenez, J. E. (2001). The effect of entrepreneurship education in the Universities of Cali. Frontiers of entrepreneurship research, Babson Conference proceedings.

Wu, S \& Wu, L., (2008), ” The impact of higher education on entrepreneurial intentions of university students in China”, Journal of Small Business and Enterprise Development. ,Vol. 15 No. 4, 2008 pp. 752-774 retrieved from www.emeraldinsight.com/1462-6004.htm 